\title{
TELLUS GEOPHYSICS
}

Understanding the structural and stratigraphic relationships between and within the Tyrone Igneous Complex and Tyrone Central Inlier has previously been hampered by poor exposure. However, a recently completed regional airborne geophysical survey over Northern Ireland has helped to resolve the crustal structure of the region. Magnetic, radiometric and electromagnetic (EM) data were acquired over the entirety of Northern Ireland during 2005-2006 as part of the Tellus Project (see GSNI, 2007). Two frequency EM datasets ( 3 and $14 \mathrm{kHz}$ ) were acquired over the Tyrone Igneous Complex and the western half of Northern Ireland in 2005 and four-frequency datasets (0.9, 3, 12 and 25 $\mathrm{kHz}$ ) across the eastern half in 2006. Total magnetic intensity (reduced to pole), first vertical derivative, analytic signal maps and EM maps over the Tyrone Igneous Complex are presented as Supplementary Information. Further detail on survey specification and geophysical data processing are presented within Beamish et al. (2007) and in the Supplementary Information.

The lower Tyrone Volcanic Group, Tyrone Plutonic Group and Tyrone Central Inlier are all characterized by short-wavelength magnetic anomalies (Gunn et al., 2008). Within the lower Tyrone Volcanic Group, laterally extensive magnetic highs correspond to units of pillowed, massive and sheet-flow basalt (e.g. Copney Pillow Lava Formation; GSNI, 1979 and 1995), magnetite-rich jaspers and local bodies of magnetite-bearing gabbro (e.g. at Beaghmore) and diabase (e.g. at Tanderagee) (Fig. 2). By contrast, the upper Tyrone Volcanic Group is predominantly non-magnetic, except within the vicinity of CashelFormil and Broughderg where gold and base-metal mineralization is prevalent (Leyshon and Cazalet, 1978; Clifford et al., 1992; Gunn et al., 2008). Geophysical characteristics of the Tyrone Plutonic Group and Tyrone Central Inlier will be discussed in subsequent publications. Faulted contacts between the Tyrone Plutonic Group, Tyrone Volcanic 
Group and Tyrone Central Inlier are best discriminated with the EM imagery, with boundaries corresponding well to previous mapping (GSNI, 1979; 1995). However, new subdivisions within the Tyrone Volcanic Group recognized through Tellus geophysics and fieldwork are outlined below. Major NE-SW trending reactivated Caledonian and Carboniferous faults (e.g. Omagh Thrust, Tempo-Sixmilecross Fault) are also apparent from sharp magnetic features which offset Palaeogene dikes (Cooper et al., 2012), as are previously unrecognized faults such as the herein named Beaghmore, Dungate and Sixtowns faults which truncate basaltic subdivisions of the Tyrone Volcanic Group.

Fig. X. Results of the Tellus airbourne geophysical survey of Northern Ireland. Survey lines were orientated at orientated at $165^{\circ}$ or $345^{\circ}, 200 \mathrm{~m}$ apart, at a flight height of $56 \mathrm{~m}$ in rural areas, rising to $240 \mathrm{~m}$ over urban areas. Two Scintrex Caesium Vapour Model CS2 magnetometers were employed to derive magnetic intensity. Sensitivity was 0.001 $\mathrm{nT}$ with a sample interval of 0.1 seconds $(\sim 7 \mathrm{~m})$. Electromagnetic data was acquired through a vertical-coplanar transmitter/receiver configuration. A Tx-Rx coil separation of $21.36 \mathrm{~m}$ was used with a sample interval of 0.25 seconds $(\sim 17.5 \mathrm{~m})$. (a) Total magnetic intensity map, reduced to pole (RTP), (b) Total magnetic intensity map, first vertical derivative (RTP-1VD), (c) Total magnetic intensity, analytic signal (TMI-AS), (d) EM low frequency (ApCond). All maps show original GSNI linework (GSNI 1979, 1983 and 1995) as in Figure 2. Grid references are according to Irish Grid. 


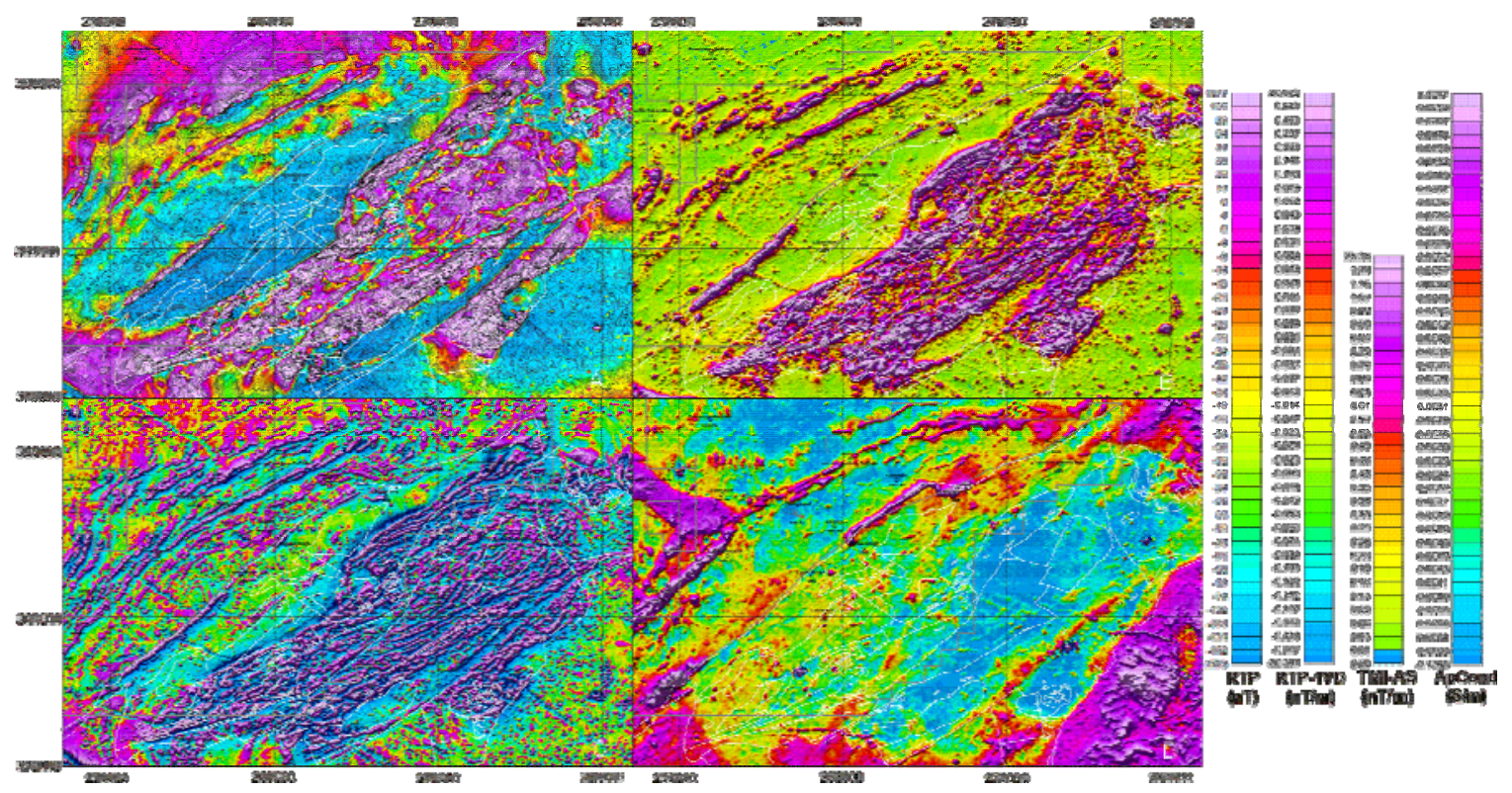




\section{Methods, Geochemistry:}

All major stratigraphic horizons within the Tyrone Volcanic Group were sampled. Major-elements were determined for powdered whole-rock samples on fused glass beads by X-ray fluorescence (XRF). Trace-elements were analysed on powder-pellets by XRF. All analyses were undertaken using a Philips ${ }^{\circledR}$ MAGIX-PRO automatic sequential wavelength dispersive XRF spectrometer at the University of Southampton. Rare earthelements (plus $\mathrm{Nb}, \mathrm{Hf}, \mathrm{Ta}, \mathrm{Th}, \mathrm{U}$ ) were determined by inductively coupled plasma mass spectrometry (ICP-MS) at the University of Southampton on the same samples using $\mathrm{HF} / \mathrm{HNO}_{3}$ digest. To ensure complete digestion of zircons and other resistant minerals, repeated digests were made until no residue remained; and results for $\mathrm{Ba}, \mathrm{Sr}, \mathrm{Rb}, \mathrm{La}, \mathrm{Th}$, $\mathrm{Y}, \mathrm{Nb}$ and $\mathrm{Zr}$ were checked between XRF and ICP-MS analysis. Accuracy (\%RD) and Precision $(\% \mathrm{RSD})$ was typically $<3 \%$ for ICP-MS analyses and $<5 \%$ for XRF analyses based on replicate analyses of a range of international standards (XRF: JR-1, JR-2, JG-3, JB-1a, JA-a; ICP-MS: BHVO-2, JB-1a, JB-3, JGB-1, JR-1). Elements with accuracy and precision $>10 \%$ (ICP-MS: Ta; XRF: Cr, Ni, Cu) are considered poor (Jenner, 1996) and were not used.

Neodymium isotope ratios were measured using a VGMicromass Sector 54 thermal ionization mass spectrometer (TIMS) at the University of Southampton. ${ }^{143} \mathrm{Nd} /{ }^{144} \mathrm{Nd}$ was measured in multidynamic mode, exponentially corrected for instrumental fractionation relative to ${ }^{146} \mathrm{Nd} /{ }^{144} \mathrm{Nd}=0.7219$. The JNdi standard gave a value of $0.512091 \pm 14(2 \mathrm{sd}$, $\mathrm{n}=20$ ), with data corrected to 0.512115 (Tanaka et al. 2000). An age correction was performed (DePaolo and Wasserburg, 1976) to account for radioactive decay and ingrowth of ${ }^{143} \mathrm{Nd}$; values for that time are reported as $\varepsilon \mathrm{Nd}_{(\mathrm{t})}$. Modern CHUR was taken to be 0.512638 and 0.1967 for ${ }^{143} \mathrm{Nd} /{ }^{144} \mathrm{Nd}$ and ${ }^{147} \mathrm{Sm} /{ }^{144} \mathrm{Nd}$ respectively (Hamilton et al. 1983). The decay constant of ${ }^{147} \mathrm{Sm}$ is $6.54 \times 10^{-12} \mathrm{yr}^{-1}$. Depleted mantle model ages 
$\left(\tau_{\mathrm{DM}}\right)$ are calculated after DePaolo (1981) assuming present day ${ }^{143} \mathrm{Nd} /{ }^{144} \mathrm{Nd}$ and ${ }^{147} \mathrm{Sm} /{ }^{144} \mathrm{Nd}$ values of 0.51315 and 0.2137 .

\section{Methods, Geochronology:}

Six samples were selected for U-Pb (zircon) geochronology. Zircons were isolated using conventional mineral separation techniques. Prior to isotope dilution thermal ionization mass spectrometry (ID-TIMS) analyses zircons were subject to a modified version of the chemical abrasion technique (Mattinson, 2005). U-Pb ID-TIMS analyses herein utilized the EARTHTIME ${ }^{205} \mathrm{~Pb}^{233} \mathrm{U}_{-}{ }^{235} \mathrm{U}$ (ET535) tracer solution. Measurements at the NERC Isotope Geosciences Laboratory were performed on a Thermo Triton TIMS. Pb analyses were measured in dynamic mode on a MassCom SEM detector and corrected for 0.14 $\pm 0.04 \% / \mathrm{u}$. mass fractionation. Linearity and dead-time corrections on the SEM were monitored using repeated analyses of NBS 981 and U500. Uranium was measured in static Faraday mode on $1011 \mathrm{ohm}$ resistors or for signal intensities $<15 \mathrm{mV}$, in dynamic mode on the SEM detector. Uranium was run as the oxide and corrected for isobaric interferences with an ${ }^{18} \mathrm{O} /{ }^{16} \mathrm{O}$ composition of 0.00205 (IUPAC value and determined through direct measurement at NIGL). Single analysis U-Pb dates and uncertainties were calculated using the algorithms of Schmitz and Schoene (Schmitz and Schoene, 2007) and ${ }^{235} \mathrm{U} /{ }^{205} \mathrm{~Pb}$ ratio for ET535 of $100.18 \pm 0.1 \%$. All common $\mathrm{Pb}$ in the analyses was attributed to the blank and subtracted based on the isotopic composition and associated uncertainties analysed over time. The ${ }^{206} \mathrm{~Pb} /{ }^{238} \mathrm{U}$ ratios and dates were corrected for initial ${ }^{230} \mathrm{Th}$ disequilibrium using an assumed Th/U[magma] of $3 \pm 1$ applying the algorithms of Schärer (Schärer, 1984) resulting in an increase in the ${ }^{206} \mathrm{~Pb} /{ }^{238} \mathrm{U}$ dates of $\sim 100 \mathrm{kyr}$. Weighted mean ${ }^{206} \mathrm{~Pb} /{ }^{238} \mathrm{U}$ dates and associated uncertainties were calculated using Isoplot (Ludwig, 1991). 
Errors for $\mathrm{U}-\mathrm{Pb}$ dates are reported in the following format: $\pm \mathrm{X}(\mathrm{Y})[\mathrm{Z}]$, where $\mathrm{X}$ is the internal or analytical uncertainty in the absence of systematic errors (tracer calibration and decay constants), $Y$ includes the quadratic addition of tracer calibration error (using a conservative estimate of the standard deviation of $0.1 \%$ for the $\mathrm{Pb} / \mathrm{U}$ ratio in the tracer), and $\mathrm{Z}$ includes the quadratic addition of both the tracer calibration error and additional ${ }^{238} \mathrm{U}$ decay constant errors of Jaffey et al. (Jaffey et al. 1971). All analytical uncertainties are calculated at the $95 \%$ confidence interval. These ${ }^{238} \mathrm{U} /{ }^{206} \mathrm{~Pb}$ dates are traceable back to SI units via the gravimetric calibration of the EARTHTIME U-Pb tracer and the determination of the ${ }^{238} \mathrm{U}$ decay constant (Condon et al. 2007; Jaffey et al. 1971). The mean square weighted deviation (MSWD) has been calculated for each population used for weighted mean calculations all fall within the range expected for a single population of a given sample size (Wendt and Carl, 1991).

\section{References for Supplementary Material not in manuscript:}

Beamish, D., Cuss, R.J., Lahti, M., Scheib, C., and Tartaras, E., 2007, The Tellus airborne geophysical survey of Northern Ireland: Final processing report: British Geological Survey Internal Report, IR/06/136, pp. 74.

Condon, D., Schoene, B., Bowring, S., Parrish, R., McLean, N., Noble, S., and Crowley, Q., 2007, EARTHTIME; isotopic tracers and optimized solutions for highprecision U-Pb ID-TIMS geochronology: Eos, Transactions, American Geophysical Union, v. 88, no. 52, Suppl.

Cooper, M.R., Anderson, H., Walsh, J.J., van Dam, C.L., Young, M.E., Earls, G., and Walker, A., 2012, Palaeogene Alpine tectonics and Icelandic plume-related magmatism and deformation in Northern Ireland: Journal of the Geological Society, London, v. 169, p. 29-36. 
DePaolo, D.J., 1981, Trace element and isotopic effects of combined wallrock assimilation and fractional crystalization: Earth and Planetary Science Letters, v. 53, p. 189-202.

DePaolo, D.J., and Wasserburg, G.J., 1976, Nd isotopic variations and petrogenetic models: Geophysical Research Letters, v. 3, p. 249-252.

Fornari, D.J., Perfit, M.R., Malahoff, A., and Embley, R., 1983, Geochemical studies of abyssal lavas recovered by DSRV Alvin from Eastern Galapagos Rift, Inca Transform, and Ecuador Rift, 1, Major Element Variations in Natural glasses and spacial distribution of lavas: Journal of Geophysical Research, v. 88, p.10519-10529.

Hamilton, P.J., O'Nions, R.K., Bridgwater, D., and Nutman, A., 1983, Sm-Nd studies of Archaean metasediments and metavolcanics from West Greenland and their implications for the Earth's early history: Earth and Planetary Science Letters, v. 62, p. 263-272.

Hey, R.N., Johnson, G.L., and Lowrie, A, 1977, Recent tectonic evolution of the Galapagos area and plate motions in the east Pacific: Geological Society of America Bulletin, v. 88, p.1404-1420.

Hey, R.N., Duennebier, F.K., and Morgan, W.J., 1980, Propagating rifts on mid-ocean ridges: Journal of Geophysical Research, v. 85, p.3647-3658.

Jaffey, A. H., Flynn, K. F., Glendenin, L. E., Bentley, W. C., and Essling, A. M., 1971, Precision measurement of half-lives and specific of ${ }^{235} \mathrm{U}$ and ${ }^{238} \mathrm{U}$.: Physics Reviews, v. C4, p. 1889-1906.

Ludwig, K. R., 1991, Isoplot - a plotting and regression program for radiogenic isotope data: USGS Open File Report, p. 91-445.

Mattinson, J. M., 2005, Zircon U-Pb chemical abrasion ("CA-TIMS") method: Combined annealing and multi-step partial dissolution analysis for improved precision and accuracy of zircon ages: Chemical Geology, v. 220, no. 1-2, p. 47-66. 
Schärer, U., 1984, The effect of initial ${ }^{230} \mathrm{Th}$ disequilibrium on young UPb ages: the Makalu case, Himalaya: Earth and Planetary Science Letters, v. 67, no. 2, p. 191204.

Schmitz, M. D., and Schoene, B., 2007, Derivation of isotope ratios, errors, and error correlations for U-Pb geochronology using Pb-205-U-235-(U-233)-spiked isotope dilution thermal ionization mass spectrometric data: Geochemistry Geophysics Geosystems, v. 8, Q08006.

Wendt, I., and Carl, C., 1991, The statistical distribution of the mean squared weighted deviation: Chemical Geology: Isotope Geoscience section, v. 86, no. 4, p. 275285. 


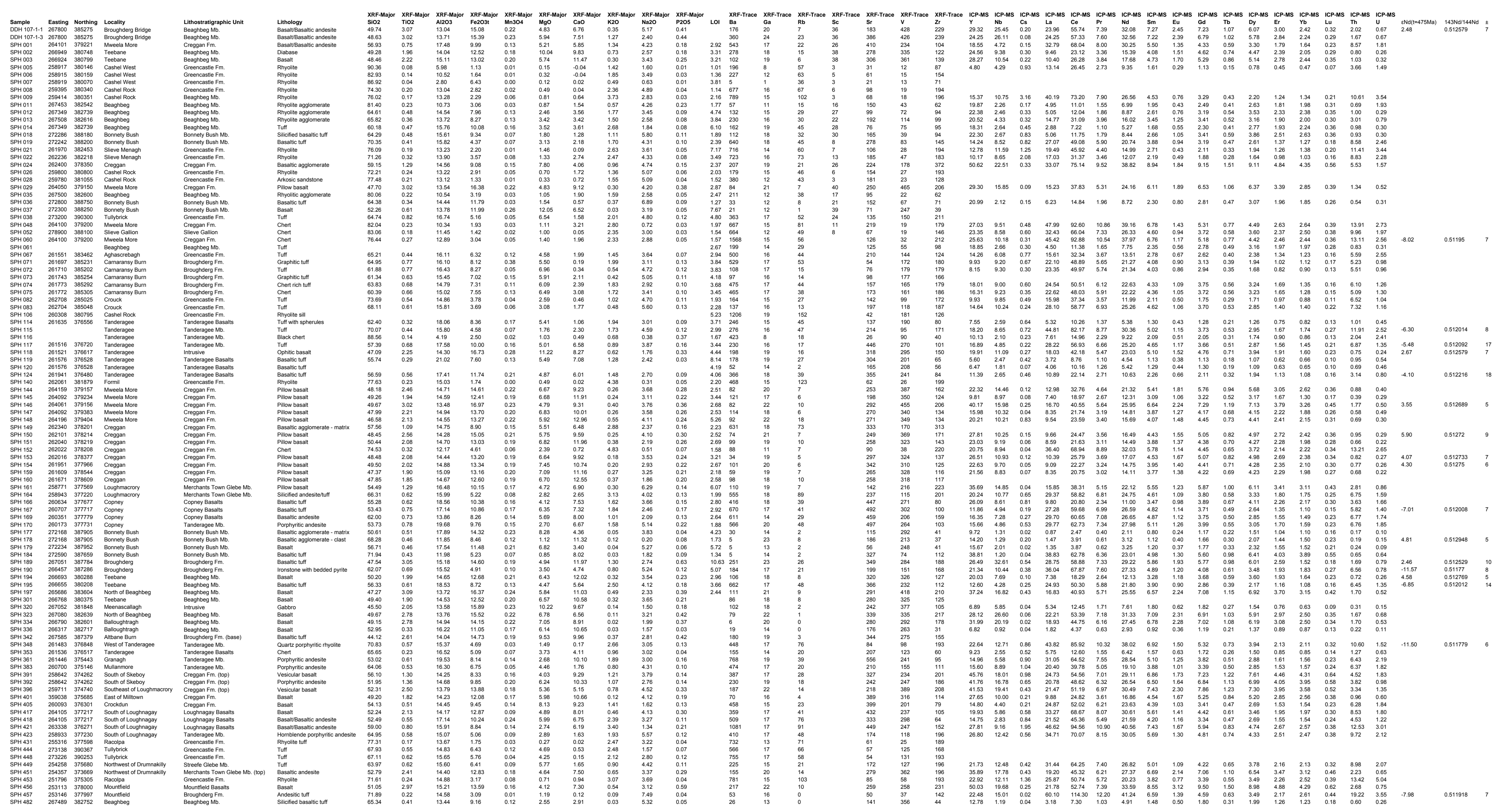

